\title{
Tinjauan sistematis studi kasus dalam penelitian kualitatif
}

\author{
Gilang Asri Nurahma ${ }^{(1)}$, Wiwin Hendriani ${ }^{(2)}$ \\ ${ }^{(1),(2)}$ Fakultas Psikologi, Universitas Airlangga, Surabaya, Indonesia
}

Along with its development, there are many different understandings of what a case study is and how to conduct scientific research using case study appropriately. The goal of this research was to identify the definitions and types of case study, as well as issues worth considering in designing case study research. Designed as qualitative research using a systematic review method, the data in this study were derived from ScienceDirect, ResearchGate, and Google Scholar. The results showed that there are various definitions and types of case study. The implication of those findings suggests the importance of researchers' capability to understand how to properly conduct a case study, how to determine cases and research boundaries, and how to appropriately analyse data.

Keywords: case study, qualitative research, systematic review

Seiring dengan perkembangannya, banyak pemahaman yang berbeda-beda mengenai apa itu studi kasus dan bagaimana cara melakukan penelitian ilmiah dengan menggunakan pendekatan studi kasus secara tepat. Tujuan penelitian ini adalah untuk menyajikan sebuah tinjauan sistematis mengenai definisi studi kasus, tipe-tipe studi kasus, serta hal-hal yang perlu diperhatikan dalam merancang penelitian studi kasus. Dirancang sebagai riset kualitatif menggunakan metode tinjauan sistematis, data dalam penelitian ini bersumber dari ScienceDirect, ResearchGate, dan Google Scholar. Hasil penelitian menunjukkan adanya definisi dan tipe-tipe studi kasus yang sangat bervariasi. Implikasi dari hasil penelitian ini menunjukkan pentingnya kemampuan peneliti untuk memahami bagaimana cara melakukan pendekatan studi kasus secara tepat, bagaimana menentukan kasus dan batasan penelitian, dan bagaimana menganalisis data secara cermat.

Kata Kunci: metode tinjauan sistematis, penelitian kualitatif, studi kasus

MEDIAPSI, 2021, Vol. 7(2), 119-129, DOI: https://doi.org/10.21776/ub.mps.2021.007.02.4

Received: 03-11-2020. Revised: 27-05-2021. Accepted: 23-07-2021. Published online: 25-12-2021

Handling Editor: Sukma Nurmala, Universitas Brawijaya, Malang, Indonesia.

*Corresponding author: Gilang Asri Nurahma, Fakultas Psikologi, Universitas Airlangga, Surabaya,

Indonesia. E-mail: gilang.asri.nurahma-2020@psikologi.unair.ac.id

This work is licensed under a Creative Commons Attribution-NonCommercial 4.0 International License.

How to cite this article in accordance with the American Psychological Association (APA) $7^{\text {th }}$ guidelines: Nurahma, G. A., \& Hendriani, W. (2021). Tinjauan sistematis studi kasus dalam penelitian kualitatif. MEDIAPSI, 7(2), 119-129. https://doi.org/10.21776/ub.mps.2021.007.02.4

\section{Pendahuluan}

Studi kasus adalah sebuah metode empiris yang menyelidiki suatu fenomena kontemporer atau kasus secara mendalam dan dalam konteks dunia nyata, yang digunakan terutama ketika batasan antara fenomena dan konteks tidak terlihat secara jelas (Yin, 2018). Pendekatan studi kasus digunakan ketika peneliti ingin mendapatkan pemahaman atas suatu masalah, peristiwa, atau fenomena yang menarik dalam konteks kehidupan nyata 
yang alami. Studi kasus juga memungkinkan peneliti untuk mendapatkan pandangan yang holistik mengenai serangkaian kejadian atau fenomena tertentu (Noor, 2008).

Penelitian studi kasus mencakup berbagai topik penelitian, mulai dari komunitas, pendidikan, kesehatan publik, bisnis dan industri, peraturan dan administrasi publik, sampai dengan masalah dan kontroversi sosial (Yin, 2012). Di Indonesia, penelitian yang menggunakan pendekatan studi kasus telah banyak dilakukan pada berbagai bidang ilmu seperti Psikologi (Briliana \& Mursito, 2017), Sosiologi (Seda dkk., 2018), Antropologi (Vos, 2016), Ilmu Politik (Munthe, 2017), dan masih banyak lagi. Tingginya minat pada penelitian studi kasus mungkin disebabkan karena penelitian studi kasus dinilai sebagai suatu metodologi yang fleksibel, menantang, dan paling umum digunakan dalam penelitian, terutama penelitian di bidang ilmu sosial (Prihatsanti dkk., 2018).

Namun sayangnya, meskipun penelitian studi kasus telah banyak digunakan dalam berbagai disiplin ilmu, studi kasus masih mendapatkan perhatian dan panduan yang paling sedikit di antara hampir semua metode penelitian yang digunakan dalam ilmu sosial. Kebanyakan literatur membahas studi kasus sebagai metodologi secara kurang mendalam. Bahkan hampir tidak ada jurnal lintas disiplin atau lintas profesi yang berfokus atau menitikberatkan pada pembahasan metode penelitian studi kasus (Yin, 2012). Hal ini menyebabkan para peneliti baru yang ingin menggunakan pendekatan studi kasus tidak benar-benar memahami apa itu studi kasus dan bagaimana membedakannya dengan jenis penelitian kualitatif lainnya (Merriam, 1998). Kurangnya definisi yang jelas dan kesimpangsiuran antara hubungan metodologi dan teori studi kasus pun juga membuat peneliti kurang cermat dalam menetapkan tujuan dari penelitian studi kasus (Stoecker, 1991).

Ketika kita berusaha menjelaskan konsep studi kasus, perlu kita pahami terlebih dahulu bahwa tidak ada definisi tunggal yang menjelaskan apa itu studi kasus (Hentz, 2017). Flyvberjg (2011) mengatakan bahwa ketika seorang peneliti membutuhkan satu definisi mengenai studi kasus, akan lebih baik jika studi kasus didefinisikan secara lebih umum dan tidak banyak mengandung kalimat atau katakata yang cermat. Namun tetap saja, sebelum melakukan penelitian studi kasus, kita perlu menentukan definisinya terlebih dahulu untuk menekankan apa karakteristik utama studi kasus yang membedakannya dengan tipe penelitian kualitatif lainnya (Starman, 2013). Yin (2003) juga menyatakan bahwa seorang peneliti perlu mengidentifikasi kasus dan tipe studi kasus yang ingin diimplementasikan. Oleh karena itu, peneliti menyajikan suatu tinjauan sistematis sebagai upaya untuk mendapatkan pemahaman yang menyeluruh mengenai apa itu studi kasus, apa saja tipe-tipe studi kasus beserta perbedaannya, dan apa saja yang perlu diperhatikan dalam merancang penelitian studi kasus.

\section{Metode \\ Partisipan dan desain penelitian}

Penelitian ini tidak melibatkan partisipan atau subjek penelitian. Hal ini disebabkan karena penelitian ini menggunakan metode tinjauan sistematis. Metode kualitatif ini merupakan metode 
yang dilakukan dengan menyusun pertanyaan yang diformulasikan secara jelas, melakukan pencarian studi-studi dan jurnal yang relevan secara intensif, menilai kualitas studi-studi lain yang sudah ditemukan, dan membuat ringkasan hasil dengan menggunakan metodologi eksplisit (Khan dkk., 2003).

\section{Prosedur dan pengukuran}

Penelitian ini tidak melibatkan pengukuran terhadap variabel penelitian karena data didasarkan pada informasi berupa teks dari beberapa online academic database. Prosedur penelitian mengacu pada lima langkah tinjauan sistematis yang direkomendasikan oleh Khan dkk. (2003). Langkah pertama adalah membuat kerangka pertanyaan yang jelas sebagai bahan tinjauan. Pertanyaan yang ingin peneliti jawab dalam artikel ini antara lain:

1. Apa yang dimaksud dengan studi kasus?

2. Apa saja tipe-tipe studi kasus dan apa perbedaan dari masing-masing tipe tersebut?

3. Apa saja hal-hal yang perlu diperhatikan dalam merancang penelitian studi kasus?

Langkah kedua adalah melakukan pencarian studi dan penelitian terdahulu yang relevan. Pencarian basis data sistematis dilakukan pada bulan Oktober 2020 untuk mengidentifikasi artikel ilmiah yang secara khusus membahas tentang metode studi kasus yang dapat diakses dan diunduh dalam versi lengkap. Basis data elektronik yang digunakan antara lain adalah Sciencedirect, ResearchGate, dan Google Scholar. Kata kunci yang digunakan untuk mencari jurnal-jurnal dan buku yang relevan antara lain "case" dan "study", "case" dan "study" dan "approach", "case" dan "study" dan

"research", "case" dan "study" dan

"method". Kata kunci lainnya mencakup

"case" dan "study" dan "methodology",

"case" dan "study" dan "qualitative" dan

"research", "case" dan "study" dan

"definition", "case" dan "study" dan

"psychology", "case" dan "study" dan

"organizational" dan "psychology",

"types" dan "of" dan "case" dan

"study", serta "case" dan "study" dan

"Indonesia".

Langkah ketiga adalah menilai kualitas jurnal yang ditemukan. Peneliti memastikan kembali apakah isi jurnal yang ditemukan dapat menjawab pertanyaan yang telah disusun pada langkah pertama secara jelas dan mendetail. Setelah melakukan tinjauan lebih lanjut pada ketiga jurnal yang telah dipilih, peneliti membuat tabulasi hasil tinjauan supaya dapat dibaca dalam bentuk yang ringkas dan sistematis.

Terakhir, peneliti menginterpretasikan dan membuat kesimpulan dari tinjauan literatur yang sudah dilakukan untuk menjawab pertanyaan yang telah disusun pada langkah pertama.

\section{Hasil}

Dari total 30 jurnal yang peneliti temukan, didapatkan tiga jurnal yang dinilai paling rinci, lengkap, dan jelas dalam menguraikan definisi studi kasus, tipe-tipe studi kasus, serta hal-hal yang perlu diperhatikan dalam proses merancang penelitian studi kasus (Baxter \& Jack, 2008; Prihatsanti dkk., 2018; Starman, 2013). Beberapa hal yang menjadi pertimbangan peneliti untuk tidak memilih 27 jurnal lainnya antara lain adalah tahun publikasi yang sudah terlalu 
lampau (lebih dari 15 tahun terakhir), isi jurnal yang membahas tipe penelitian kualitatif secara umum sehingga kurang fokus membahas studi kasus, dan isi jurnal yang kurang jelas dalam mendefinisikan studi kasus. Ringkasan hasil tinjauan dapat dilihat dalam Tabel 1.

Sebagaimana bisa dicermati pada
Tabel 1, definisi dan tipe studi kasus sangat beragam, dan terdapat sejumlah isu penting yang harus dipertimbangkan untuk melakukan studi kasus secara benar. Selanjutnya, hasil tinjauan disajikan secara rinci di bagian Diskusi untuk menjawab setiap pertanyaan.

Tabel 1. Tabulasi Data Ringkasan Hasil Tinjauan Sistematis.

\begin{tabular}{|c|c|c|c|}
\hline $\begin{array}{l}\text { Peneliti } \\
\text { (Tahun) }\end{array}$ & Definisi Studi Kasus & Tipe-tipe Studi Kasus & $\begin{array}{l}\text { Poin Penting dalam Merancang Studi } \\
\text { Kasus }\end{array}$ \\
\hline $\begin{array}{l}\text { Baxter dan } \\
\text { Jack (2008) }\end{array}$ & $\begin{array}{l}\text { Studi kasus adalah suatu } \\
\text { pendekatan penelitian } \\
\text { yang memfasilitasi } \\
\text { peneliti } \\
\text { menyelidiki } \\
\text { fenomena menggunakan } \\
\begin{array}{l}\text { sumber data yang } \\
\text { beragam. }\end{array}\end{array}$ & $\begin{array}{l}\text { Studi kasus eksplanatori } \\
\text { Studi kasus eksploratori } \\
\text { Studi kasus deskriptif } \\
\text { Studi kasus single case } \\
\text { Studi kasus multiple case } \\
\text { Studi kasus instrinsik } \\
\text { Studi kasus instrumental }\end{array}$ & $\begin{array}{l}\text { 1. Penentuan konteks penelitian, kasus } \\
\text { yang akan dianalisis, pertanyaan } \\
\text { penelitian, batasan ruang lingkup } \\
\text { penelitian, tipe studi kasus } \\
\text { 2. Mencari proposisi sebagai panduan } \\
\text { studi, pengumpulan data, dan diskusi } \\
\text { 3. Pengumpulan data dari berbagai } \\
\text { sumber } \\
\text { 4. Pengelompokkan data secara efektif } \\
\text { 5. Analisis kasus secara menyeluruh } \\
\text { 6. Pelaporan studi kasus yang mudah } \\
\text { dibaca dan dipahami }\end{array}$ \\
\hline $\begin{array}{l}\text { Starman } \\
(2013)\end{array}$ & $\begin{array}{l}\text { Studi kasus adalah tipe } \\
\text { penelitian kualitatif yang } \\
\text { menguji kompleksitas } \\
\text { dari berbagai situasi di } \\
\text { kehidupan nyata dengan } \\
\text { basis epistemologis yang } \\
\text { berbeda-beda, } \\
\text { tergantung apa yang } \\
\text { menjadi sandaran } \\
\text { peneliti, misalnya } \\
\text { tujuan, level, jangka } \\
\text { waktu, atau konteks } \\
\text { penelitian. }\end{array}$ & $\begin{array}{l}\text { Studi kasus retrospektif } \\
\text { Studi kasus snapshot } \\
\text { Studi kasus diakronik } \\
\text { Studi kasus nested } \\
\text { Studi kasus paralel } \\
\text { Studi kasus sekuensial } \\
\text { Studi kasus ateoretik atau } \\
\text { idiografik konfiguratif } \\
\text { Studi kasus disciplined } \\
\text { configurative } \\
\text { Studi kasus heuristik } \\
\text { Studi kasus theory-testing } \\
\text { Studi kasus plausibility probes } \\
\text { Studi kasus "Building Block" }\end{array}$ & $\begin{array}{l}\text { 1. Pemilihan kasus sebagai unit } \\
\text { penelitian yang bukan hanya dipilih } \\
\text { sebagai sampel representatif, namun } \\
\text { juga karena menarik minat peneliti } \\
\text { 2. Pengetahuan awal dan landasan teori } \\
\text { yang kuat } \\
\text { 3. Prosedur pengumpulan data yang } \\
\text { akurat dan komprehensif } \\
\text { 4. Dokumentasi seluruh informasi yang } \\
\text { didapatkan dari pengumpulan data } \\
\text { untuk mencapai reliabilitas } \\
\text { penelitian yang baik }\end{array}$ \\
\hline $\begin{array}{l}\text { Prihatsanti } \\
\text { dkk. (2018) }\end{array}$ & $\begin{array}{l}\text { Studi kasus } \text { adalah } \\
\text { metode ilmiah yang } \\
\text { bertujuan menyelidiki } \\
\text { kegiatan atau proses } \\
\text { kompleks yang tidak } \\
\text { mudah dipisahkan dari } \\
\text { konteks sosial di mana } \\
\text { hal itu terjadi. }\end{array}$ & $\begin{array}{l}\text { Studi kasus intrinsik } \\
\text { Studi kasus instrumental } \\
\text { Studi kasus eksplanatori } \\
\text { Studi kasus eksploratori } \\
\text { Studi kasus deskriptif }\end{array}$ & $\begin{array}{l}\text { 1. Pemilihan kasus } \\
\text { 2. Memperoleh dan mempertahankan } \\
\text { akses (keyperson) } \\
\text { 3. Pemilihan kerangka teoritis awal } \\
\text { 4. Pengumpulan data yang sistematis } \\
\text { dari berbagai sumber } \\
\text { 5. Pengelolaan pengumpulan data } \\
\text { 6. Analisis data yang cermat } \\
\text { 7. Penutupan kasus dan pembuatan } \\
\text { laporan }\end{array}$ \\
\hline
\end{tabular}




\section{Diskusi}

Menurut Baxter dan Jack (2008), studi kasus adalah suatu pendekatan penelitian yang memfasilitasi peneliti untuk menyelidiki sebuah fenomena menggunakan sumber data yang beragam. Mengacu pada definisi studi kasus yang dikemukakan oleh Simons (2009), Starman (2013) menyatakan bahwa studi kasus adalah tipe penelitian kualitatif yang menguji kompleksitas dari berbagai situasi di kehidupan nyata dengan basis epistemologis yang berbeda-beda, tergantung apa yang menjadi sandaran peneliti, misalnya tujuan, level, jangka waktu, atau konteks penelitian. Sedangkan menurut Prihatsanti dkk. (2018), studi kasus adalah metode ilmiah yang bertujuan menyelidiki suatu kegiatan atau proses kompleks yang tidak mudah dipisahkan dari konteks sosial di mana hal itu terjadi. Lebih lanjut, Prihatsanti dkk. (2018) juga menjelaskan bahwa penelitian studi kasus melibatkan penyelidikan yang terperinci, pengumpulan data yang dilakukan pada periode waktu, fenomena, dan konteks tertentu yang bertujuan untuk memberikan analisis tentang konteks dan proses yang berkaitan dengan isu teoritis yang sedang diteliti.

Banyak peneliti yang mendefinisikan metodologi studi kasus dengan mengacu pada dua pendekatan utama yang dikemukakan oleh Stake (1995) dan Yin (2003). Keduanya mendasarkan pendekatan mereka terhadap studi kasus menggunakan paradigma konstruktivis, yang mengklaim bahwa kebenaran bersifat relatif dan bergantung pada perspektif seseorang. Paradigma ini menyadari pentingnya pemaknaan subjektif manusia, namun tidak langsung menolak beberapa gagasan mengenai objektivitas. Oleh karena itu, pendekatan paradigma konstruktivis dalam studi kasus memungkinkan terjadinya kolaborasi antara peneliti dengan partisipan penelitian, dimana partisipan penelitian dapat secara terbuka menceritakan pengalamannya dan mendeskripsikan pandangannya terhadap realita. Peneliti pun lebih mampu memahami pemikiran atau sudut pandang yang mendasari tindakan partisipan (Baxter \& Jack, 2008).

Dari ketiga definisi di atas, dapat dilihat bahwa definisi yang dikemukakan oleh Starman (2013) lebih bersifat umum namun tetap dapat menjelaskan karakteristik utama yang membedakan studi kasus dengan tipe penelitian kualitatif lainnya. Definisi tersebut sejalan dengan pendapatnya bahwa definisi studi kasus biasanya bersifat agak umum dan tidak mengandung variasi klasifikasi atau jenis-jenis studi kasus, karena hampir tidak mungkin untuk mencakup semua jenis studi dalam satu definisi. Namun, Prihatsanti dkk. (2018) menyatakan bahwa sebelum melakukan penelitian studi kasus, peneliti perlu memahami dan menentukan terlebih dahulu jenis studi kasus apa yang sesuai dengan tujuan studi secara keseluruhan.

Serupa dengan Prihatsanti dkk. (2018), Baxter dan Jack (2008) menguraikan tipe studi kasus yang mengacu pada Yin (2003) dan Stake (1995). Yin (2003) mengkategorikan studi kasus menjadi studi kasus eksplanatori, studi kasus eksplorasi, dan studi kasus deskriptif, serta studi kasus tunggal dan studi kasus ganda. Stake (1995) mengkategorikan studi kasus menjadi studi kasus intrinsik dan studi kasus instrumental. Sementara itu, Starman (2013) mengklasifikasikan studi kasus 
single dan multiple case berdasarkan dimensi waktu. Untuk studi kasus single case, studi kasus dibedakan menjadi studi kasus retrospektif, studi kasus snapshot, studi kasus diakronik. Studi kasus multiple case dipilah ke dalam studi kasus nested, studi kasus paralel, dan studi kasus sekuensial. Selain itu, Starman (2013) juga menguraikan tipe studi kasus berdasarkan pembentukan teorinya, antara lain studi kasus ateoretik atau idiografik konfiguratif, studi kasus disciplined configurative, studi kasus heuristic, studi kasus theory-testing, studi kasus plausibility probes, dan studi kasus "building block". Definisi dari masingmasing tipe studi kasus dapat dilihat dalam Tabel 2.

Tabel 2. Definisi dari Tipe-tipe Studi Kasus.

\begin{tabular}{|c|c|}
\hline $\begin{array}{c}\text { Tipe Studi } \\
\text { Kasus }\end{array}$ & Definisi \\
\hline Eksplanatori & $\begin{array}{l}\text { Tipe studi kasus yang digunakan ketika peneliti berusaha menjawab suatu pertanyaan yang ingin } \\
\text { menjelaskan dugaan hubungan kausal dalam intervensi kehidupan nyata yang terlalu kompleks } \\
\text { jika dilakukan dengan survey atau eksperimen (Yin, dalam Baxter \& Jack, 2008). Pada kasus } \\
\text { yang kompleks dan multivariat, analisis dilakukan dengan teknik pencocokan pola (Yin, dalam } \\
\text { Prihatsanti dkk., 2018). }\end{array}$ \\
\hline Eksplorasi & $\begin{array}{l}\text { Tipe studi kasus yang digunakan untuk menyelidiki situasi-situasi dimana intervensi yang } \\
\text { dilakukan tidak memberikan hasil yang jelas (Yin, dalam Baxter \& Jack, 2008). Pengumpulan } \\
\text { data dapat dilakukan sebelum adanya pertanyaan penelitian dan hipotesis. Dalam beberapa } \\
\text { penelitian sosial, jenis penelitian ini dianggap sebagai studi pendahuluan, yang berguna untuk } \\
\text { menentukan protokol/urutan akhir yang digunakan (Yin, dalam Prihatsanti dkk., 2018). }\end{array}$ \\
\hline Deskriptif & $\begin{array}{l}\text { Tipe studi kasus yang digunakan untuk mendeskripsikan suatu intervensi atau fenomena dalam } \\
\text { konteks kehidupan nyata (Yin, dalam Baxter \& Jack, 2008), dan mengharuskan peneliti untuk } \\
\text { memulai penelitian dengan suatu teori deskriptif (Yin, dalam Prihatsanti dkk., 2018). }\end{array}$ \\
\hline Single case & $\begin{array}{l}\text { Desain studi yang digunakan ketika kasus merupakan kasus kritis untuk menguji teori, atau kasus } \\
\text { yang unik, atau kasus umum yang dapat menambah pemahaman peneliti pada peristiwa tertentu, } \\
\text { atau kasus yang sebelumnya tidak dapat diakses, atau kasus longitudinal (Yin, dalam Prihatsanti } \\
\text { dkk., 2018). }\end{array}$ \\
\hline Multiple case & $\begin{array}{l}\text { Desain studi kasus yang digunakan ketika peneliti ingin menguji kondisi atau temuan serupa dari } \\
\text { suatu kasus yang dapat direplikasi (Yin, dalam Prihatsanti dkk., 2018). Multiple case } \\
\text { memungkinkan peneliti untuk menyelidiki perbedaan di dalam dan antar kasus yang berbeda, } \\
\text { serta memprediksi hasil yang serupa ataupun hasil yang kontras dari beberapa kasus berdasarkan } \\
\text { teori (Yin, dalam Baxter \& Jack, 2008). }\end{array}$ \\
\hline Intrinsik & $\begin{array}{l}\text { Tipe studi kasus yang digunakan ketika peneliti ingin lebih memahami suatu kasus tertentu bukan } \\
\text { karena kasusnya mewakili masalah lain atau mengandung konstruksi abstrak tertentu, tapi karena } \\
\text { peneliti benar-benar memiliki ketertarikan yang murni terhadap kasus (Stake, dalam Baxter \& } \\
\text { Jack, 2008). Tujuannya bukan untuk memahami fenomena umum melainkan untuk memenuhi } \\
\text { minat peneliti pada fenomena tertentu, sehingga meskipun peneliti dapat membangun sebuah teori } \\
\text { dari studi kasus intrinsik, hal tersebut bukan menjadi tujuan utama peneliti (Stake, dalam } \\
\text { Prihatsanti dkk., 2018). }\end{array}$ \\
\hline
\end{tabular}


Tabel 2. (Lanjutan).

\begin{tabular}{|c|c|}
\hline $\begin{array}{l}\text { Tipe Studi } \\
\text { Kasus }\end{array}$ & Definisi \\
\hline Instrumental & $\begin{array}{l}\text { Tipe studi kasus yang digunakan ketika peneliti memilih kasus yang diteliti untuk memberikan } \\
\text { wawasan tentang masalah atau membantu peneliti memperbaiki teori (Stake, dalam Prihatsanti } \\
\text { dkk., 2018). Kasus yang diteliti berperan sebagai instrumen pendukung dalam memfasilitasi } \\
\text { pemahaman peneliti tentang hal lain. Kasus yang diteliti dilihat secara mendalam, diteliti } \\
\text { konteksnya, dan diperinci aktivitas di dalamnya untuk membantu peneliti menemukan tujuan } \\
\text { penelitian (Stake, dalam Baxter \& Jack, 2008). }\end{array}$ \\
\hline Retrospektif & $\begin{array}{l}\text { Tipe studi kasus yang melibatkan pengumpulan data yang berkaitan dengan fenomena masa lalu } \\
\text { dalam bentuk apa pun. Peneliti melihat kembali suatu fenomena, situasi, orang, atau peristiwa, } \\
\text { dan mempelajarinya dalam suatu kesatuan historisnya (Thomas, dalam Starman, 2013). }\end{array}$ \\
\hline Snapshot & $\begin{array}{l}\text { Tipe studi yang menguji suatu kasus dalam satu periode waktu tertentu, seperti peristiwa terkini, } \\
\text { suatu hari dalam kehidupan seseorang, buku harian, dan lain-lain. Analisisnya dilakukan } \\
\text { berdasarkan waktu kejadian, baik yang terjadi dalam sebulan, seminggu, sehari, atau bahkan } \\
\text { sesingkat satu jam. Studi ini menggambarkan dirinya sebagai sebuah Gestalt dalam jangka waktu } \\
\text { yang ketat (Thomas, dalam Starman, 2013). }\end{array}$ \\
\hline Diakronik & $\begin{array}{l}\text { Tipe studi yang meneliti kasus yang berubah-ubah sepanjang waktu, serupa dengan studi } \\
\text { longitudinal (Thomas, dalam Starman, 2013). }\end{array}$ \\
\hline Nested & $\begin{array}{l}\text { Tipe studi kasus multiple case yang melibatkan perbandingan elemen dalam suatu kasus. Dalam } \\
\text { studi ini, perinciannya dilakukan pada unit-unit utama di dalam analisis sehingga memperoleh } \\
\text { keutuhan hasil analisis dari kasus yang lebih luas daripada tipe studi kasus multiple case biasa } \\
\text { (Thomas, dalam Starman, 2013). }\end{array}$ \\
\hline Paralel & $\begin{array}{l}\text { Tipe studi kasus yang digunakan untuk meneliti beberapa kasus yang terjadi secara bersamaan } \\
\text { (Thomas, dalam Starman, 2013). }\end{array}$ \\
\hline Sekuensial & $\begin{array}{l}\text { Tipe studi kasus yang digunakan untuk meneliti kasus yang terjadi secara berurutan, dan terdapat } \\
\text { asumsi bahwa apa yang terjadi dalam satu waktu atau periode akan memengaruhi kejadian } \\
\text { berikutnya (Thomas, dalam Starman, 2013). }\end{array}$ \\
\hline $\begin{array}{l}\text { Ateoretikal } \\
\text { atau } \\
\text { indiografik } \\
\text { konfiguratif }\end{array}$ & $\begin{array}{l}\text { Tipe studi kasus ilustratif yang tidak berkontribusi secara langsung terhadap suatu teori (George } \\
\& \text { Bennett, dalam Starman, 2013). }\end{array}$ \\
\hline $\begin{array}{l}\text { Disciplined } \\
\text { configurative }\end{array}$ & $\begin{array}{l}\text { Tipe studi kasus yang menggunakan teori yang sudah mapan untuk menjelaskan suatu kasus } \\
\text { (George \& Bennett, dalam Starman, 2013). }\end{array}$ \\
\hline Heuristik & $\begin{array}{l}\text { Tipe studi kasus yang digunakan untuk mengidentifikasi cara baru yang belum pernah ditemukan } \\
\text { sebelumnya. Dalam studi ini, kasus-kasu yang marjinal, menyimpang, atau pencilan mungkin } \\
\text { akan sangat berguna (George \& Bennett, dalam Starman, 2013). }\end{array}$ \\
\hline Theory-testing & $\begin{array}{l}\text { Tipe studi kasus yang menilai validitas dan ruang lingkup suatu teori tunggal atau beberapa teori } \\
\text { yang saling bersaingan (George \& Bennett, dalam Starman, 2013). }\end{array}$ \\
\hline $\begin{array}{l}\text { Plausibility } \\
\text { probes } \\
\text { "Building } \\
\text { Block" }\end{array}$ & $\begin{array}{l}\text { Tipe studi kasus pendahuluan yang digunakan untuk menentukan apakah diperlukan pemeriksaan } \\
\text { kasus yang lebih lanjut (George \& Bennett, dalam Starman, 2013). } \\
\text { Tipe studi kasus yang meneliti beberapa tipe atau subtipe dari suatu fenomena, yang ketika } \\
\text { digabung dapat berkontribusi sebagai teori yang lebih komprehensif (George \& Bennett, dalam } \\
\text { Starman, 2013). }\end{array}$ \\
\hline
\end{tabular}

Prihatsanti dkk. (2018) menguraikan bahwa terdapat empat kondisi spesifik di mana peneliti dapat mempertimbangkan penggunaan desain penelitian studi kasus, antara lain ketika: (a) fokus penelitiannya adalah untuk menjawab pertanyaan 
penelitian "bagaimana" dan "mengapa" suatu fenomena dapat terjadi, (b) peneliti tidak dapat memanipulasi perilaku subjek yang terlibat dalam penelitian, (c) peneliti ingin menutupi kondisi kontekstual tertentu karena peneliti yakin hal tersebut relevan dengan fenomena yang ingin diteliti, atau (d) tidak ada batasan yang jelas antara fenomena dan konteks. Studi kasus cocok digunakan untuk meneliti suatu fenomena yang tidak dapat dipisahkan dari konteksnya, tetapi dapat menjadi suatu penelitian yang menarik ketika ditujukan untuk memahami bagaimana suatu perilaku dapat memengaruhi atau dipengaruhi oleh konteks tertentu (Hartley, 2004).

Studi kasus yang diaplikasikan dengan baik akan memungkinkan peneliti untuk dapat menyelidiki suatu masalah tidak hanya melalui satu lensa, melainkan beberapa lensa yang beragam, sehingga mampu membantu peneliti menemukan dan memahami fenomena yang diteliti dari berbagai aspek (Baxter \& Jack, 2008). Oleh karena itu, peneliti merasa perlu menyajikan hal-hal apa saja yang perlu diperhatikan dalam merancang penelitian studi kasus.

Pertama, memilih kasus. Dalam pemilihan studi kasus, Starman (2013) menyarankan untuk memilih kasus atau permasalahan sebagai unit penelitian (misalnya satu individu, keluarga atau kelompok lainnya, organisasi, atau komunitas) berdasarkan minat atau ketertarikan peneliti. Pemilihan kasus bukan berdasar pada alasan yang berkaitan dengan sampel representatif, melainkan karena kasus tersebut menarik, tidak biasa, mencolok, dapat memberikan suatu perubahan pada karakteristik dan kekhususan objek penelitian, dimana subjek dan objek penelitian berinteraksi dalam suatu hubungan yang dinamis.

Kedua, menentukan batasan penelitian. Baxter dan Jack (2008) menekankan pada penentuan kasus sebagai unit penelitian dengan mempertanyakan pada diri peneliti sendiri, misalnya dengan pertanyaan semacam "apakah saya ingin menganalisa seorang individu, atau suatu program, atau suatu proses, atau perbedaan antara beberapa organisasi?". Dengan mempertanyakan dan mendiskusikan pertanyaan-pertanyaan semacam itu, peneliti akan lebih mudah dalam menentukan konteks penelitian dan menggambarkan kasus apa yang sebenarnya ingin diteliti. Peneliti dapat mengembangkan pertanyaan penelitian dan menentukan tipe studi kasus yang cocok digunakan berdasarkan tujuan penelitian. Peneliti juga dapat menentukan pertanyaan penelitian sederhana dengan fokus "bagaimana" dan "mengapa" karena tanpa fokus penelitian, peneliti akan kewalahan dalam mengolah banyaknya data (Prihatsanti dkk., 2018).

Ketiga, mencari proposisi dari literatur, pengalaman pribadi atau profesional, teori, atau generalisasi yang berdasar pada data empiris sebagai panduan dalam melakukan studi, mengumpulkan data, dan menganalisa kasus. Masih berhubungan dengan poin pertama, Starman (2013) berpendapat bahwa pemilihan kasus yang didasarkan pada pengetahuan sebelumnya akan berujung pada perencanaan penelitian yang lebih matang, terutama ketika disertai dengan pemahaman landasan teori yang kuat.

Keempat, mengumpulkan data dengan sistematis, akurat, dan komprehensif. Terdapat beberapa sumber 
data yang dapat digunakan peneliti dalam melakukan studi kasus, antara lain dokumentasi, rekaman, wawancara, artefak fisik, pengamatan langsung, dan pengamatan terlibat (participant observation). Penggunaan suatu basis data dapat meningkatkan reliabilitas studi kasus karena basis data membantu peneliti untuk melacak, mengatur, dan mengakses kembali berbagai sumber data seperti catatan, dokumen-dokumen penting, tabel, narasi, foto, atau audio file (Baxter \& Jack, 2008). Prosedur pengumpulan data dan dokumentasi yang dilakukan secara akurat dan komprehensif juga tentunya akan membantu peneliti mencapai reliabilitas studi kasus yang baik (Starman, 2013). Namun dengan bervariasinya sumber data yang tersedia, sebaiknya peneliti kembali bertanya kepada diri sendiri mengenai "apakah proses yang dilakukan berasal dari informan yang cukup luas? Apakah ada data yang tidak mendukung? Apakah ada catatan dokumenter yang dapat diperiksa?". Peneliti pun harus paham kapan proses pengumpulan data berhenti dilakukan dengan mempertimbangkan biaya dan efektifitas pengelolaan data (Prihatsanti dkk., 2018).

Keenam, menganalisis data secara cermat dengan melakukan pengelompokkan topik tertentu berdasarkan tema utama, pertanyaan utama, atau menggunakan bantuan tabel untuk mengidentifikasi suatu pola dari seluruh data yang telah terkumpul (Prihatsanti dkk., 2018). Dalam menganalisis kasus, peneliti dapat kembali pada proposisi jika kasus telah ditentukan pada tahap awal (Yin, 2003). Hal yang perlu dihindari dalam tahap menganalisis kasus adalah memperlakukan setiap sumber data secara independen dan hasil temuannya dilaporkan secara terpisah. Peneliti perlu memahami kasus secara keseluruhan, bukan hanya beberapa bagian dari kasus atau hanya faktor-faktor yang memengaruhi kasus (Baxter \& Jack, 2008).

Terakhir, membahas temuan dan membuat laporan penelitian. Tujuan dari pembuatan laporan adalah untuk mendeskripsikan penelitian dengan cara yang komprehensif sehingga memungkinkan pembaca merasa seolaholah mereka adalah partisipan aktif dalam penelitian dan dapat menentukan ada atau tidaknya temuan penelitian yang dapat mereka aplikasikan pada situasi mereka sendiri (Baxter \& Jack, 2008). Tidak ada cara tunggal yang tepat dalam pelaporan studi kasus. Meskipun demikian, Yin (2003) menyarankan enam metode pelaporan yang dapat digunakan, antara lain linier, komparatif, kronologis, pembuatan teori, suspense, dan tidak berurutan (unsequenced).

\section{Kesimpulan}

Penelitian ini telah menemukan bahwa studi kasus memiliki berbagai macam tipe dan didefinisikan secara bervariasi. Temuan tersebut berimplikasi pada pentingnya peneliti yang berminat terhadap studi kasus untuk secara cermat dan spesifik dalam menetapkan jenis atau tipe studi kasus dalam riset kualitatif mereka. Langkah ini sangat relevan untuk memfasilitasi peneliti untuk mampu secara tepat melakukan studi kasus.

Penelitian ini masih mengandung kelemahan. Untuk menutupi kelemahan ini, studi lanjutan bisa menggunakan online academic database lainnya untuk mengakses artikel ilmiah berkualitas mengenai studi kasus seperti Microsoft 
Academic, Directory of Open Access Journals (DOAJ), Academia.edu, dan ProQuest. Solusi ini sangat bermanfaat untuk menguji sejauh mana temuan-

\section{Daftar Pustaka}

Baxter, P., \& Jack, S. (2008). Qualitative case study methodology: Study design and implementation for novice researchers. The Qualitative Report, 13(4), 544-559. https://doi.org/10.46743/2160$3715 / 2008.1573$

Briliana, V., \& Mursito, N. (2017). Exploring antecedents and consequences of Indonesian Muslim youths' attitude towards halal cosmetic products: A case study in Jakarta. Asia Pacific Management Review, 22(4), 176-184. http://doi.org/10.1016/j.apmrv.2017. 07.012

Flyvbjerg, B. (2011). Case study. In N. K. Denzin \& Y. S. Lincoln (Eds.), The Sage handbook of qualitative research (pp. 301-316). SAGE Publications.

Hartley, J. (2004). Case study research. In D. Cassel \& G. Symon (Eds.), Essential guide to qualitative methods in organizational research. SAGE Publications.

Hentz, P. (2017). Overview of case study research. In M. De Chesnay (Ed.), Qualitative designs and Methods in Nursing (pp.1-10). Springer.

Khan, K. S., Kunz, R., Kleijnen, J., \& Antes, G. (2003). Five steps to conducting a systematic review. Journal of the Royal Society of Medicine, 96(3), 118-121. http://doi.org/10.1258/jrsm.96.3.118 temuan dalam penelitian ini mengenai studi kasus bersifat konsisten dan valid.

Merriam, $\mathrm{S}$.

B. (1998). Qualitativeresearch and case study applications in education. revised and expanded from case study research in education. JosseyBass Publishers.

Munthe, H. M. (2017). Phenomenon of women marginalization in poor family in pakpak community (A case study in Pegagan Julu Village, Sumbul Subdistrict, Dairi RegencyNorth Sumatra-Indonesia). Journal of Arts and Humanities, 6(6), 38-51. https://doi.org/10.18533/journal.v6i6 .1196

Noor, K. B. M. (2008). Case study: A strategic research methodology. American Journal of Applied Sciences, 5(11), 1602-1604. https://doi.org/10.3844/ajassp.2008.1 602.1604

Prihatsanti, U., Suryanto, S., \& Hendriani, W. (2018). Menggunakan studi kasus sebagai metode ilmiah dalam Psikologi. Buletin Psikologi,26(2), 126-136.

http://doi.org/10.22146/buletinpsikol ogi.38895

Seda, F. S., Setyawati, L., Pera, Y. H. T., \& Febriani, R. (2018). Social policies, social exclusion \& social well-being in Southeast Asia: A case study of Papua, Indonesia. Economics \& Sociology, 11(3), 147-160. http://doi.org/10.14254/2071789X.2018/11-3/9 
Simons, H. (2009). Case study research in practice. SAGE publications.

Stake, R. E. (1995). The art of case study research. Sage.

Starman, A. B. (2013). The case study as a type of qualitative research. Journal of Contemporary Educational Studies/Sodobna Pedagogika, 64(1), 28-43.

https://www.semanticscholar.org/pap

er/The-case-study-as-a-type-of-

qualitative-research-

Starman/1cc27a1b28050194da8bef5 b2ab807386baa286e

Stoecker, R. (1991). Evaluating and rethinking the case study. The Sociological Review, 39(1), 88-112. https://doi.org/10.1111/j.1467954X.1991.tb02970.x
Vos, R. E. D. (2016). Multi-functional lands facing oil palm monocultures: A case study of a land conflict in West Kalimantan, Indonesia. ASEAS-Austrian Journal of South-East Asian Studies, 9(1), 11-32. https://doi.org/10.14764/10.ASEAS2016.1-2

Yin, R. K. (2003). Case study research: Design and methods ( $3^{\text {rd }}$ ed.). SAGE Publications, Inc.

Yin, R. K. (2012). Applications of case study research. SAGE Publications, Inc.

Yin, R. K. (2018). Case study research and applications. SAGE Publications, Inc. 